Support Care Cancer. 2012 November ; 20(11): 2999-3008. doi:10.1007/s00520-012-1576-7.

\title{
Hepatitis B virus management to prevent reactivation after chemotherapy: a review
}

\author{
Jessica P. Hwang, \\ The University of Texas MD Anderson Cancer Center, Houston, TX, USA \\ USA jphwang@mdanderson.org \\ John M. Vierling, \\ Baylor College of Medicine, Houston, TX, USA \\ Andrew D. Zelenetz, \\ Memorial Sloan-Kettering Cancer Center, New York City, NY, USA \\ Susan C. Lackey, and \\ The University of Texas MD Anderson Cancer Center, Houston, TX, USA \\ Rohit Loomba \\ The University of California San Diego, La Jolla, CA, USA
}

Department of General Internal Medicine, 1515 Holcombe Blvd., Unit 1465, Houston, TX 77030,

\section{Abstract}

\begin{abstract}
Purpose-Reactivation of hepatitis B virus (HBV) infection after chemotherapy can lead to liver failure and death. Conflicting recommendations regarding HBV screening in cancer patients awaiting chemotherapy mean that some patients at risk for HBV reactivation are not being identified and treated with prophylactic antiviral therapy.
\end{abstract}

\begin{abstract}
Methods-We performed a narrative review of the existing evidence regarding screening for and management of HBV infection among patients with cancer using Ovid Medline, PubMed, and the Cochrane Library.

Results-Our review showed inconsistencies in the definition and management strategies for HBV reactivation. The timeframe of reactivation is variable, and its molecular mechanisms are not clear. There are five effective antiviral agents that can be used as prophylaxis to prevent reactivation of $\mathrm{HBV}$ infection in cancer patients; however, the optimal drug and duration of therapy are unknown. Reactivation is more commonly reported in patients with hematologic malignancies receiving rituximab treatment, but reactivation can occur after other chemotherapies and in patients with solid tumors. Screening with all three screening tests- $\mathrm{HBsAg}$, anti- $\mathrm{HBc}$, and anti-HBs - allows the most thorough interpretation of a patient's serologic profile and assessment of reactivation risk; however, decision-making and cost-effectiveness studies are needed to determine optimal screening strategies.
\end{abstract}

\footnotetext{
(C) Springer-Verlag 2012

Correspondence to: Jessica P. Hwang.
}

Conflict of interest disclosures Drs. Hwang, Vierling, Zelenetz, and Loomba served on an Advisory Board for reactivation of HBV infection for Gilead Sciences. Dr. Hwang has received research support from Bristol-Myers Squibb. Dr. Vierling has received research support from and serves as a Scientific Advisor for Gilead Sciences, Bristol-Myers Squibb, Roche, and Merck. Dr. Zelenetz serves as a Scientific Advisor for Gilead Sciences, Roche/Genentech, and GlaxoSmithKline. Dr. Loomba has received research support from Daiichi Sankyo and is a Scientific Advisor for Gilead Sciences and Gene Probe. 
Conclusions-Prevention of reactivation of HBV infection depends on identification of patients at risk and initiation of antiviral prophylaxis, but data to guide screening and treatment strategies are lacking. Additional research is necessary to accurately define and predict reactivation, identify best antiviral treatment strategies, and identify cost-effective HBV screening strategies.

\section{Keywords}

Hepatitis B virus; Reactivation; Chemotherapy; Cancer; Review

\section{Introduction}

Prevention of reactivation of hepatitis B virus (HBV) infection ("HBV reactivation") has been a subject of debate in the oncology community since 2008, when the Centers for Disease Control and Prevention (CDC) recommended HBV screening of all cancer patients awaiting chemotherapy [1] (Table 1). The American Association for the Study of Liver Diseases (AASLD) [2] recommends screening patients at risk for HBV infection, as do the Institute of Medicine [3], the American Society of Clinical Oncology (ASCO) [4], and the National Comprehensive Cancer Network (NCCN) [5]. ASCO and NCCN also recommend HBV screening in patients awaiting specific forms of treatment, such as stem cell transplantation or rituximab therapy [4, 5]. Unfortunately, national HBV screening recommendations for cancer patients are not harmonized, and many oncologists do not effectively screen patients at risk for HBV infection [6]. Thus, patients with HBV infection may be at risk for reactivation after chemotherapy because they are not identified or initiated on antiviral prophylaxis.

Widespread screening may be reasonable since many patients are unaware that they have HBV infection [7, 8] or identifiable risk factors for HBV infection $[9,10]$. Supporting widespread screening is the fact that no effective clinical tools are available to help physicians identify demographic and behavioral risk factors for HBV infection. In addition, no large-scale studies in the US have been conducted to identify the populations at risk for HBV reactivation and their level of risk. However, widespread screening may also be problematic given the relatively low prevalence of chronic HBV infection in the general US population and concerns about screening costs.

The conflicting national recommendations about HBV screening before initiation of chemotherapy are the result of a lack of convincing data. Recently, several reviews have been published on HBV reactivation [11-13]. Still lacking, however, is a clear strategy for obtaining the convincing data needed to reach consensus on the best HBV screening strategy to ensure that all patients with cancer who are at risk of $\mathrm{HBV}$ reactivation have their $\mathrm{HBV}$ status identified before chemotherapy.

In this focused narrative review, we summarize the existing evidence regarding screening for and management of HBV infection among patients with cancer awaiting chemotherapy. Where convincing data are lacking, we suggest steps needed to acquire such data. We conducted a comprehensive search of Ovid Medline (1946 to July 25, 2012), PubMed (1946 to July 25, 2012), and the Cochrane Library using the search terms "hepatitis B virus," "reactivation," and "chemotherapy" with a detailed search using specific chemotherapy drug names. We also included "screen" and "test" in addition to the names of hepatitis B tests, such as "HBsAg," "anti-HBc," and "anti-HBs." References in the retrieved papers were also reviewed. 


\section{How should reactivation of HBV infection be defined?}

Currently, there are no uniform diagnostic criteria for HBV reactivation. This is due in part to the limitations of retrospective studies, the unethical nature of natural history studies, and low levels of HBV screening and subsequent prospective identification of cases of reactivation. $\mathrm{HBV}$ reactivation after immunosuppression is characterized by the reappearance of active necroinflammatory liver disease in patients with the HBsAg carrier state (positive HBsAg, positive anti-HBc, negative anti-HBs, and undetectable HBV DNA), patients with occult $\mathrm{HBV}$ infection (negative $\mathrm{HBsAg}$, positive anti-HBc, and negative anti$\mathrm{HBs}$ ), or patients convalescent from prior $\mathrm{HBV}$ infection (negative $\mathrm{HBsAg}$, positive anti$\mathrm{HBc}$, and positive anti-HBs) [2] (Table 2).

Retrospective studies must often rely on few HBV serologic markers, which results in inconsistent criteria for diagnosing reactivation. Lok et al. defined hepatitis after chemotherapy as an increase in alanine aminotransferase (ALT) level to at least three times the baseline value, resulting in a level higher than 100 IU/L [14]. This definition was later modified by Yeo et al. defined HBV reactivation as an increase in ALT level to at least three times the baseline value and to a level above the upper limit of the normal range ( $>58 \mathrm{IU} / \mathrm{L}$ ) or any ALT level over $100 \mathrm{IU} / \mathrm{L}$ [15]. Hepatitis due to HBV reactivation has been defined as a tenfold increase in HBV DNA level or the reappearance of detectable HBV DNA [14, 15]. However, HBV DNA testing is not routinely performed unless a patient has been shown to have HBV infection; thus, HBV DNA has only an indirect role in diagnosing HBV reactivation.

\section{When does reactivation occur?}

HBV reactivation can occur anywhere from within 2 weeks after completion of an initial chemotherapy treatment [16] to more than 1 year after the cessation of treatment [17]. Several studies have addressed the reasons for this variability. HBV reactivation can occur after the cessation of immunosuppressive agents [18-20], presumably as the result of stimulation of HBV replication and restoration of host immune responses to infected hepatocytes. However, one study showed that the glucocorticoid-receptor site in the HBV genome is stimulated by glucocorticoids, which may result in HBV DNA replication [21]. Another study showed that doxorubicin directly stimulates HBV DNA replication and subsequent production of HBV antigens, which are recognized by the host immune response [22]. Future studies focusing on mechanisms of HBV reactivation may lead to a better understanding of the variability of its timing after initiation of chemotherapy. Such knowledge may be critical for development of optimal preventative and therapeutic strategies.

\section{What are the immunologic and molecular mechanisms underlying HBV reactivation?}

Patients infected with HBV harbor covalently closed circular (ccc) HBV DNA replicative intermediates in the nuclei of hepatocytes. After acute infection, loss of HBsAg and HBV DNA and appearance of anti-HBs indicate viral clearance; however, ccc HBV DNA remains in hepatocytes for years, is controlled by the immune system, and, conversely, plays an important role in maintaining immunity against HBV [23]. The ccc HBV DNA can cause reactivation when host immunity is weakened as a result of immunosuppressive therapy [24]. HBV-specific cytotoxic T lymphocytes and serum antibodies can be detected years after infection [25]. True hepatitis results from restoration of a cytotoxic $\mathrm{T}$ cell-mediated response to $\mathrm{HBV}$-infected hepatocytes [25]. 
Nonimmune pathways have also been implicated in HBV reactivation. In a study of transgenic mice infected with $\mathrm{HBV}$, the combination of irradiation of the liver plus interleukin-6 therapy caused in vitro HBV replication, mainly mediated through the STAT3 signaling pathway [26]. Mutations in the precore regions of HBV DNA resulting from a G to A substitution at nucleotide 1896 have been associated with HBV reactivation [27-30].

HBV can infect chimpanzees, and species-specific HBV causes natural infections in ducks, woodchucks, and squirrels; however, none of these experimental animal models is sufficient for the studies required to understand the viral, molecular, and immune mechanisms culminating in HBV-reactivation hepatitis [31]. Such studies might result in the discovery of predictors of $\mathrm{HBV}$ reactivation after chemotherapy.

\section{What are the identified risk factors for HBV reactivation?}

Patients with positive HBsAg tests have the highest rates of HBV reactivation, reported to be up to $48 \%$ in a prospective study of 100 Chinese patients with non-Hodgkin lymphoma (NHL) [14]. In a prospective study of widespread screening in Hong Kong, $38 \%$ of HBsAgpositive patients with hematologic malignancies and 15\% of HBsAg-positive patients with solid tumors had reactivation [15]. In a study of both hematologic and solid-tumor patients in France, 84 were found to have negative HBsAg but positive anti-HBc [32]. Of these, over $8 \%$ had reactivation, and all patients with reactivation had hematologic malignancies.

Any patient with previous or current $\mathrm{HBV}$ infection is at risk for reactivation. Table 2 shows HBV seromarkers and their interpretation. Patients with negative HBsAg and positive anti$\mathrm{HBc}$ are still at risk because mutant $\mathrm{HBsAg}$ may lead to false-negative HBsAg test results $[32,33]$ or because HBsAg titers may be undetectable [34]. HBsAg, anti-HBc, and anti-HBs immunoassays have reported sensitivity and specificity of over $92 \%$ [35-38].

HBV reactivation has been well documented in patients with hematologic malignancies [15, 39-42], and widespread screening for HBV is recommended for patients with lymphoma [43] and patients awaiting hematopoietic stem cell transplantation $[4,44]$. There have been an increasing number of reports of reactivation [12, 45-49] after administration of rituximab, a monoclonal antibody against $\mathrm{CD} 20$ used to treat hematologic malignancies by depleting CD20-positive B cells, and this has prompted calls for universal HBV screening of patients awaiting rituximab treatment $[44,46,48]$. In a study of 110 patients who received rituximab [46], six patients had either positive $\mathrm{HBsAg}$ or positive anti-HBc, and five of these six had reactivation. Reactivation has also occurred in patients with hematologic malignancies during treatment with other monoclonal antibodies, including ibritumomab tiuxetan [50] and alemtuzumab [51]. Other chemotherapies used to treat hematologic malignancies that have been associated with reactivation include CHOP (cyclophosphamide, doxorubicin, vincristine, and prednisone) for NHL [52], bendamustine for chronic lymphocytic leukemia (CLL) [53] and NHL [54], chlorambucil for CLL [55], and imatinib mesylate for myeloid leukemia [56]. Corticosteroids are also associated with significant risk of HBV reactivation [21]. Corticosteroid-containing treatments were associated with a higher rate of reactivation (73\%) than corticoid-free regimens (38\%) [16].

Although reactivation is more commonly reported in patients with hematologic malignancies, the risk of HBV reactivation is also substantial in patients with solid tumors. Patients with breast cancer who received anthracycline [57, 58] or cyclophosphamide, fluorouracil, docetaxel, or epirubicin [15] have experienced HBV reactivation and subsequent death. In a prospective study of 41 breast cancer patients with positive $\mathrm{HBsAg}$ tests who received chemotherapy according to standard international guidelines [58], 41\% had HBV reactivation after chemotherapy, and more than $70 \%$ of these patients with reactivation experienced premature discontinuation or delay of chemotherapy. A patient 
with glioblastoma who received temozolomide [59] had HBV reactivation, as did patients with lung cancer, colon cancer, stomach cancer, germ cell tumor, and other solid tumors who received various chemotherapy agents $[15,29,60,61]$.

A prospective study from China showed that male gender, younger age, lymphoma diagnosis, and hepatitis $\mathrm{B}$ e antigen ( $\mathrm{HBe} \mathrm{Ag}$ ) seropositivity were associated with $\mathrm{HBV}$ reactivation in patients receiving cytotoxic chemotherapy, $60 \%$ of whom were started on deferred antiviral therapy after diagnosis of hepatitis [15]. In other studies in China, high HBV viral load before chemotherapy administration was shown to be the main risk factor associated with HBV reactivation in breast cancer patients [62,63].

We need population-based estimates of the prevalences of HBV infection and reactivation among patients with cancer in the US. Since natural history studies of reactivation after immunosuppression would be unethical because effective prophylaxis is available and recommended, large multicenter cooperative efforts to uniformly identify predictors of reactivation in patients receiving antiviral prophylaxis will be necessary. In addition, validated risk tools are needed to help physicians determine who to screen for HBV infection and estimate risks of reactivation after immunosuppression.

\section{What is the best antiviral therapy?}

Currently, seven treatments are available for chronic HBV infection: two formulations of interferon (conventional and pegylated; they cause bone marrow suppression and thus are not recommended for patients with cancer) and five nucleoside or nucleotide analogues: lamivudine, adefovir, entecavir, telbivudine, and tenofovir [64-66]. Though all five nucleoside/nucleotide analogues are potent antivirals; none of them totally eradicates HBV.

Among patients with chronic HBV infection and cancer who are awaiting chemotherapy, the initial goal of anti-HBV therapy is prompt reduction of HBV replication before initiation of chemotherapy. Most studies conducted to reduce the risk of reactivation in cancer patients receiving chemotherapy have been carried out in Asia and have utilized lamivudine, one of the first antivirals shown to be effective against HBV. Previous systematic reviews and meta-analyses [17, 67-69] showed that lamivudine substantially decreased the rate of liverassociated complications after chemotherapy in cancer patients with chronic HBV infection. Loomba et al. showed that prophylactic lamivudine significantly reduced the risk of HBV reactivation, HBV-related hepatitis, HBV-related fulminant hepatitis, and HBV-related mortality $[67,68]$. This proof of efficacy is what led the AASLD and CDC to change their guidelines to recommend screening for HBV before initiation of chemotherapy.

Lamivudine, telbivudine, and adefovir have substantial resistance rates that increase over time [2] and thus are not generally recommended for long-term therapy; however, for patients who anticipate a short course of chemotherapy and have a low viral loadespecially asymptomatic chronic carriers of HBV with normal ALT - and thus require prophylaxis only for a brief period, these drugs may be acceptable and perhaps more costeffective. However, in this setting, cessation of antiviral therapy should be followed by monitoring of ALT and HBV DNA for 6-12 months to minimize the risk of reactivation. The rate of genotypic resistance (mutations that confer resistance) to lamivudine in patients with virologic breakthrough has been reported to be up to 15\%[70], and such mutations have resulted in poor outcomes in cancer patients who received lamivudine prophylaxis during chemotherapy and for 6 months after stem cell transplantation [71].

Entecavir is a promising prophylactic antiviral in patients with cancer [72-75], specifically patients with high HBV DNA levels. Although no large studies of entecavir have been conducted, the newer antivirals such as entecavir and tenofovir have the advantage of low to zero rates of resistance [76], especially in patients with high baseline HBV DNA levels who 
are anticipated to require longer courses of chemotherapy and thus long-term antiviral therapy. Entecavir has been found to have a greater antiviral effect [77] and a much lower rate of virologic breakthrough and resistance [76] than lamivudine [2]. Lymphoma patients with HBV infection treated with entecavir had lower rates of HBV reactivation and chemotherapy delays than patients treated with lamivudine [74]. However, entecavir has been associated with relapse of HBV infection after withdrawal in lymphoma patients [78]. In a study of patients without cancer, entecavir was associated with increased short-term mortality in patients who had acute exacerbation of chronic HBV infection [79]. Future studies in patients with cancer treated with immunosuppression will be important to better understand the benefits and drawbacks of entecavir and other newer agents.

Previous decision-making and cost-effectiveness studies of lamividine prophylaxis before chemotherapy in lymphoma patients known to have HBV infection $[68,80]$ showed that prophylaxis was beneficial and cost-effective in terms of reducing cancer deaths [80] and improving survival rates [68]. Another cost-effectiveness study, this one of universal HBV screening among patients with solid tumors [81], showed that universal HBV screening with $\mathrm{HBsAg}$ and anti-HBc was not cost-effective in patients with early stage breast cancer receiving adjuvant chemotherapy and patients with end-stage non-small cell lung cancer beginning palliative chemotherapy. However, that study showed that universal HBsAg (without anti-HBc) screening was cost-effective in the breast cancer patients receiving adjuvant chemotherapy [81]. In addition, a study in lymphoma patients showed that universal screening with HBsAg was cost-effective [82]. Future cost-effectiveness studies should focus on both patients with solid tumors and patients with hematologic malignancies, include various types and doses of immunosuppression, and incorporate risk factors for HBV infection. However, such studies need to be informed by more accurate assessments of prevalence and reactivation risk.

\section{What is the optimal duration of antiviral therapy?}

To date, no randomized controlled studies have been conducted comparing antiviral treatments to prevent $\mathrm{HBV}$ reactivation. With the advent of newer and more effective therapies for the treatment of chronic HBV infection, clinical trials are needed to test whether these newer and more potent agents are more effective than lamivudine in reducing the long-term risk of HBV reactivation among patients with cancer and, most important, to determine the optimal duration of antiviral prophylaxis with these new agents. There are no published studies on the optimal duration of antiviral prophylaxis in cancer patients receiving chemotherapy, and this is a key gap in knowledge since withdrawal hepatitis and mortality may occur after discontinuation of antiviral therapy [41]. Since reactivation may occur after cessation of chemotherapy and during the recovery of patients' immune function, the optimal length of antiviral prophylaxis may depend on many factors, including dose and type of immunosuppression. In the absence of definitive data and until further studies are done, we recommend that cessation of antiviral therapy be followed by monitoring of ALT and HBV DNA levels for 6-12 months to minimize the risk of reactivation. The duration of antiviral therapy may need to be further prolonged depending on the type of immunosuppression and anticipated time to recovery of immune function.

\section{Who should be screened for HBV infection?}

The rationale for screening for HBV infection before chemotherapy is well accepted among hepatologists. However, most of the available data are based on studies conducted in highprevalence countries in Asia [67]. There are limited data with which to assess whether routine screening is cost-effective in low-prevalence countries and whether screening should be restricted to patients with risk factors for HBV infection. To conduct a cost-effectiveness 
analysis, baseline estimates of the prevalence of $\mathrm{HBV}$ infection and the rate of reactivation with various forms of chemotherapy are needed. Baseline prevalence is unknown in many regions of the US. Future validated tools to identify patients at risk for HBV infection and reactivation will help oncologists and primary care physicians decide who to screen.

\section{What are the known risk factors for HBV infection?}

The CDC [1] and AASLD [2] have established groups at high risk for HBV infection based on cultural origin and behavioral characteristics. HBV is transmitted perinatally from infected mother to child and by prolonged, close person-to-person contact, especially contact among children who have open cuts and sores. Persons who were born in geographical areas of moderate to high prevalence of HBV infection are at risk and should be screened. These areas include parts of Asia, Africa, the Middle East, Eastern and Mediterranean Europe, South America, and Central America. HBV is also transmitted by percutaneous and sexual exposures. Household and sexual contacts of persons with HBV infection should be screened. In addition, persons who have injected drugs, have had multiple sexual partners, or have a history of sexually transmitted diseases are at risk and should be screened.

\section{What HBV tests should be used?}

Screening for HBV infection may include $\mathrm{HBsAg}$, anti-HBc, and/or anti-HBs. Using all three tests allows the most thorough and complete interpretation of the serologic profile of a patient and is the recommended strategy of the CDC [1]. The patterns of positive test results yield specific clinical information about a patient's HBV status (Table 2). The AASLD also supports the use of all three tests but considers an alternative, possibly more efficient strategy of using anti-HBc first and then testing for HBsAg and anti-HBs if results of the initial anti-HBc screening test are positive [2]. However, these recommendations are based on little evidence, and future studies should be designed to clarify the optimal use of the available serologic tests. ASCO recommends screening using the HBsAg test, and in some cases the anti-HBc test, but does not endorse screening with anti-HBs [4].

HBsAg positivity clearly indicates increased risk of reactivation. However, in patients who are $\mathrm{HBsAg}$ negative but anti-HBc positive, there is no consensus regarding the magnitude of reactivation risk, leading to lack of clarity as to whether prophylactic therapy should be initiated and, if so, when to stop prophylaxis. Patients who have negative HBsAg but positive anti-HBc test results may either have occult HBV infection or be convalescent from previous infection. Patients with occult HBV infection may have viral mutants that render their HBsAg undetectable with conventional assays [83, 84], may carry mutations capable of inhibiting viral replication [83], or may have HBsAg levels lower than the detectable limit of the assay [34]; furthermore, patients may be in the "immunologic window" when HBsAg is undetectable but anti-HBs is not yet detectable [34]. Although anti-HBc may be considered a surrogate for DNA amplification and a sentinel marker of occult HBV infection [85], polymerase chain reaction have shown that HBV DNA levels are detectable in 0-35 \% [8688] of patients who are negative for $\mathrm{HBsAg}$ and positive for anti-HBc; this wide range has been attributed to virologic, immunologic, and methodologic causes, along with HBV endemnicity [34]. Patients who received intravenous immunoglobulin within the preceding 4 weeks may have a positive anti-HBc test result because of passive transfer, leading to misinterpretation of serologic test results [89]. Patients with previous HBV infection may lose anti-HBs after rituximab therapy [90], and this loss of anti-HBs has been shown to be a risk factor for reactivation [47]. Thus, HBV DNA testing should be done routinely during and after the cessation of rituximab therapy.

Previous studies [45, 91-94] have shown HBV-related complications in patients with hematologic malignancies with negative $\mathrm{HBsAg}$ and positive anti-HBc test results. These 
patients should undergo HBV DNA testing before chemotherapy and be closely monitored during and after chemotherapy [95]. Patients with CLL have a prevalence of occult HBV infection, i.e., no detectable HBsAg but detectable HBV DNA - three times that of age- and sex-matched controls, but this may reflect the role of HBV infection in the pathogenesis of lymphoproliferative disorders of B cell lineage [96], for example, NHL.

Among patients with lymphoma and occult HBV infection, there have been reported cases of reactivation after rituximab therapy $[45,91,92,97,98]$, including fatal cases [93, 94, 99101]. One US study found the prevalence of $\mathrm{HBsAg}$ negative but anti-HBc positive test results to be $11 \%$ among a population of predominantly NHL patients [102]. There have been calls for testing patients with lymphoma for anti-HBc in addition to HBsAg [103] and for administering antiviral prophylaxis to lymphoma patients with negative HBsAg and positive anti-HBc before chemotherapy [104]; these recommendations are included in the NCCN guidelines for NHL [43].

Despite the presence of anti-HBs, HBV replication may persist for more than two decades after acute infection and is kept at low levels by cytotoxic $\mathrm{T}$ lymphocyte responses [23]. NHL patients who were positive for anti-HBs and negative for $\mathrm{HBsAg}$ (anti-HBc unknown) later became positive for HBsAg and had detectable HBV DNA after rituximab therapy [19] or bone marrow transplantation [105]. Besides rituximab, patients with CLL who were initially positive for anti-HBc and anti-HBs later became positive for $\mathrm{HBsAg}$ and had detectable HBV DNA 6 months after receiving chlorambucil and prednisolone [104]. Patients such as these should be considered to harbor HBV in the liver and should be monitored for reactivation with periodic HBsAg and HBV DNA tests during chemotherapy [106, 107].

Another reason to screen using anti-HBs is that having anti-HBs may be protective against reactivation $[90,97,108]$, and thus this test, along with serial HBV DNA levels, could be useful in monitoring for reactivation during and after chemotherapy. Although HBV vaccination protects healthy persons from $\mathrm{HBV}$ infection, it does not protect against escape mutant viruses. Likewise, although administration of immune globulin provides passive transfer of anti-HBs and anti-HBc (and subsequently causes false-positive findings on serologic tests [89, 109]), it does not provide complete protection because of escape mutants with more mutations than can be addressed through the donor antibodies [106].

\section{Conclusions}

The controversies about HBV screening and management among patients with cancer have arisen, in part, from a lack of clear and convincing data. To make progress in this field, we will need expert consensus and then, importantly, validation regarding the definition of reactivation, the timing of reactivation, and diagnostic testing for reactivation. Future studies to validate and assess the utility of risk tools for screening will be beneficial. We will need well-designed studies to determine the best antiviral therapy or combination and the optimal duration of antiviral therapy and follow-up care. Comprehensive cost-effectiveness studies are necessary to identify best screening practices, including whether widespread or targeted screening is best. In addition, future studies with better animal models should incorporate immunologic and functional genomic elements to identify risk and predictors of reactivation in a very heterogeneous population of patients with hematologic malignancies and solid tumors. With a collaborative approach to patient care, involving the coordinated efforts of specialists in oncology, gastroenterology, hepatology, and infectious diseases, we can develop the best and most comprehensive care for cancer patients with HBV infection. 


\section{Acknowledgments}

We are grateful to the following individuals at MD Anderson Cancer Center: Angelic Castillo, Department of General Internal Medicine, for administrative assistance; Laurissa Gann, MSLS, Research Medical Library, for assistance with literature review; and Stephanie Deming, BA, Department of Scientific Publications, for editing the manuscript.

Supported by the National Institutes of Health through MD Anderson's Cancer Center Support Grant, CA016672. Dr. Hwang is a recipient of a National Cancer Institute Career Development Award (K07CA132955). Dr. Loomba is supported by the American Gastroenterological Association Foundation-Sucampo-ASP Designated Research Award in Geriatric Gastroenterology, National Institute of Diabetes and Digestive and Kidney Diseases Career Development Award (K23DK090303), and a T. Franklin Williams Scholarship Award. Dr. Loomba is also supported by Atlantic Philanthropies, Inc, the John A. Hartford Foundation, the Association of Specialty Professors, and the American Gastroenterological Association. The content is solely the responsibilities of the authors and does not necessarily represent the official views of the funding agencies.

\section{References}

1. Weinbaum CM, Williams I, Mast EE, Wang SA, Finelli L, Wasley A, Neitzel SM, Ward JW. Centers for Disease Control and Prevention. Recommendations for identification and public health management of persons with chronic hepatitis B virus infection. MMWR Recomm Rep. 2008; 57:1-20. [PubMed: 18802412]

2. Lok AS, McMahon BJ. Chronic hepatitis B: update 2009. Hepatology. 2009; 50:661-662. [PubMed: 19714720]

3. Institute of Medicine. Hepatitis and liver cancer: a national strategy for prevention and control of hepatitis B and C. Washington DC: IOM; 2010.

4. Artz AS, Somerfield MR, Feld JJ, Giusti AF, Kramer BS, Sabichi AL, Zon RT, Wong SL. American Society of Clinical Oncology provisional clinical opinion: chronic hepatitis B virus infection screening in patients receiving cytotoxic chemotherapy for treatment of malignant diseases. J Clin Oncol. 2010; 28:3199-3202. [PubMed: 20516452]

5. National Comprehensive Cancer Network. Practice guidelines in oncology: prevention and treatment of cancer-related infections, 2009. 2009 available from: http://www.nccn.org/ professionals/physician_gls/pdf/infections.pdf.

6. Tran TT, Rakoski MO, Martin P, Poordad F. Screening for hepatitis B in chemotherapy patients: survey of current oncology practices. Aliment Pharmacol Ther. 2010; 31:240-246. [PubMed: 19814747]

7. Lin SY, Chang ET, So SK. Why we should routinely screen Asian American adults for hepatitis B: a cross-sectional study of Asians in California. Hepatology. 2007; 46:1034-1040. [PubMed: 17654490]

8. Hwang JP, Mohseni M, Gor BJ, Wen S, Guerrero H, Vierling JM. Hepatitis B and hepatitis C prevalence and treatment referral among Asian Americans undergoing community-based hepatitis screening. Am J Public Health. 2010; 1:10.

9. Brook MG, Lever AM, Kelly D, Rutter D, Trompeter RS, Griffiths P, Thomas HC. Antenatal screening for hepatitis B is medically and economically effective in the prevention of vertical transmission: three years experience in a London hospital. Q J Med. 1989; 71:313-317. [PubMed: 2594961]

10. Prevention of perinatal transmission of hepatitis B virus: prenatal screening of all pregnant women for hepatitis B surface antigen. MMWR Morb Mortal Wkly Rep. 1988; 37:341-346. [PubMed: 2967425]

11. Keam B, Lee JH, Im SA, Yoon JH. Why, when, and how to prevent hepatitis B virus reactivation in cancer patients undergoing chemotherapy. J Natl Compr Cancer Netw. 2011; 9:465-477.

12. Villadolid J, Laplant KD, Markham MJ, Nelson DR, George TJ Jr. Hepatitis B reactivation and rituximab in the oncology practice. Oncologist. 2010; 15:1113-1121. [PubMed: 20930099]

13. Lee R, Vu K, Bell CM, Hicks LK. Screening for hepatitis B surface antigen before chemotherapy: current practice and opportunities for improvement. Curr Oncol. 2010; 17:32-38. [PubMed: 21151407] 
14. Lok AS, Liang RH, Chiu EK, Wong KL, Chan TK, Todd D. Reactivation of hepatitis B virus replication in patients receiving cytotoxic therapy. Report of a prospective study.

Gastroenterology. 1991; 100:182-188. [PubMed: 1983820]

15. Yeo W, Chan PK, Zhong S, Ho WM, Steinberg JL, Tam JS, Hui P, Leung NW, Zee B, Johnson PJ. Frequency of hepatitis B virus reactivation in cancer patients undergoing cytotoxic chemotherapy: a prospective study of 626 patients with identification of risk factors. J Med Virol. 2000; 62:299307. [PubMed: 11055239]

16. Cheng AL, Hsiung CA, Su IJ, Chen PJ, Chang MC, Tsao CJ, Kao WY, Uen WC, Hsu CH, Tien HF, Chao TY, Chen LT, Whang-Peng J. Steroid-free chemotherapy decreases risk of hepatitis B virus (HBV) reactivation in HBV-carriers with lymphoma. Hepatology. 2003; 37:1320-1328. [PubMed: 12774010]

17. Kohrt HE, Ouyang DL, Keeffe EB. Systematic review: lamivudine prophylaxis for chemotherapyinduced reactivation of chronic hepatitis B virus infection. Aliment Pharmacol Ther. 2006; 24:1003-1016. [PubMed: 16984494]

18. Coppola N, Tonziello G, Pisaturo M, Messina V, Guastafierro S, Fiore M, Iodice V, Sagnelli C, Stanzione M, Capoluongo N, Pasquale G, Sagnelli E. Reactivation of overt and occult hepatitis B infection in various immunosuppressive settings. J Med Virol. 2011; 83:1909-1916. [PubMed: 21915865]

19. Dervite I, Hober D, Morel P. Acute hepatitis B in a patient with antibodies to hepatitis B surface antigen who was receiving rituximab. N Engl J Med. 2001; 344:68-69. [PubMed: 11187122]

20. Sera T, Hiasa Y, Michitaka K, Konishi I, Matsuura K, Tokumoto Y, Matsuura B, Kajiwara T, Masumoto T, Horiike N, Onji M. Anti-HBs-positive liver failure due to hepatitis B virus reactivation induced by rituximab. Intern Med. 2006; 45:721-724. [PubMed: 16819252]

21. Tur-Kaspa R, Burk RD, Shaul Y, Shafritz DA. Hepatitis B virus DNA contains a glucocorticoidresponsive element. Proc Natl Acad Sci U S A. 1986; 83:1627-1631. [PubMed: 3006059]

22. Hsu CH, Hsu HC, Chen HL, Gao M, Yeh PY, Chen PJ, Cheng AL. Doxorubicin activates hepatitis $\mathrm{B}$ virus (HBV) replication in HBV-harboring hepatoblastoma cells. A possible novel mechanism of HBV reactivation in HBV carriers receiving systemic chemotherapy. Anticancer Res. 2004; 24:3035-3040. [PubMed: 15517913]

23. Rehermann B, Ferrari C, Pasquinelli C, Chisari FV. The hepatitis B virus persists for decades after patients' recovery from acute viral hepatitis despite active maintenance of a cytotoxic Tlymphocyte response. Nat Med. 1996; 2:1104-1108. [PubMed: 8837608]

24. Vierling JM. The immunology of hepatitis B. Clin Liver Dis. 2007; 11:727-759. vii-viii. [PubMed: 17981227]

25. Wursthorn K, Wedemeyer H, Manns MP. Managing HBV in patients with impaired immunity. Gut. 2010; 59:1430-1445. [PubMed: 20525968]

26. Chou CH, Chen PJ, Jeng YM, Cheng AL, Huang LR, Cheng JC. Synergistic effect of radiation and interleukin-6 on hepatitis B virus reactivation in liver through STAT3 signaling pathway. Int J Radiat Oncol Biol Phys. 2009; 75:1545-1552. [PubMed: 19327909]

27. Alexopoulou A, Theodorou M, Dourakis SP, Karayiannis P, Sagkana E, Papanikolopoulos K, Archimandritis AJ. Hepatitis B virus reactivation in patients receiving chemotherapy for malignancies: role of precore stop-codon and basic core promoter mutations. J Viral Hepat. 2006; 13:591-596. [PubMed: 16907845]

28. Yeo W, Zhong S, Chan PK, Ho WM, Wong HT, Chan AS, Johnson PJ. Sequence variations of precore/core and precore promoter regions of hepatitis B virus in patients with or without viral reactivation during cytotoxic chemotherapy. J Viral Hepat. 2000; 7:448-458. [PubMed: 11115057]

29. Steinberg JL, Yeo W, Zhong S, Chan JY, Tam JS, Chan PK, Leung NW, Johnson PJ. Hepatitis B virus reactivation in patients undergoing cytotoxic chemotherapy for solid tumours: precore/core mutations may play an important role. J Med Virol. 2000; 60:249-255. [PubMed: 10630955]

30. Chen PM, Yao NS, Wu CM, Yang MH, Lin YC, Hsiao LT, Yen CC, Wang WS, Fan FS, Chiou TJ, Liu JH, Lo SJ. Detection of reactivation and genetic mutations of the hepatitis B virus in patients with chronic hepatitis B infections receiving hematopoietic stem cell transplantation. Transplantation. 2002; 74:182-188. [PubMed: 12151729] 
31. Bissig KD, Wieland SF, Tran P, Isogawa M, Le TT, Chisari FV, Verma IM. Human liver chimeric mice provide a model for hepatitis B and C virus infection and treatment. J Clin Invest. 2010; 120:924-930. [PubMed: 20179355]

32. Borentain P, Colson P, Coso D, Bories E, Charbonnier A, Stoppa AM, Auran T, Loundou A, Motte A, Ressiot E, Norguet E, Chabannon C, Bouabdallah R, Tamalet C, Gerolami R. Clinical and virological factors associated with hepatitis $\mathrm{B}$ virus reactivation in $\mathrm{HBs} A g-$ negative and anti-HBc antibodies-positive patients undergoing chemotherapy and/or autologous stem cell transplantation for cancer. J Viral Hepat. 2010; 17:807-815. [PubMed: 20002298]

33. Alexopoulou A, Dourakis SP, Pandelidaki H, Archimandritis AJ, Karayiannis P. Detection of a hepatitis B surface antigen variant emerging in a patient with chronic lymphocytic leukaemia treated with fludarabine. J Med Virol. 2006; 78:1043-1046. [PubMed: 16789016]

34. Arraes LC, Ximenes R, Andrieu JM, Lu W, Barreto S, Pereira LM, Castelo A. The biological meaning of anti-HBC positive result in blood donors: relation to HBV-DNA and to other serological markers. Rev Inst Med Trop Sao Paulo. 2003; 45:137-140. [PubMed: 12870062]

35. Huzly D, Schenk T, Jilg W, Neumann-Haefelin D. Comparison of nine commercially available assays for quantification of antibody response to hepatitis B virus surface antigen. J Clin Microbiol. 2008; 46:1298-1306. [PubMed: 18256221]

36. Schmidt M, Nubling CM, Scheiblauer H, Chudy M, Walch LA, Seifried E, Roth WK, Hourfar MK. Anti-HBc screening of blood donors: a comparison of nine anti-HBc tests. Vox Sang. 2006; 91:237-243. [PubMed: 16958836]

37. Miedouge M, Legrand-Abravanel F, Lalanne C, Saune K, Izopet J. Laboratory evaluation of the UniCel DxI 800 analyser (Beckman Coulter) for detecting HBV and HCV serological markers. J Clin Virol. 2009; 44:134-137. [PubMed: 19110466]

38. U.S. Preventive Services Task Force. Screening for hepatitis B virus infection in pregnancy: U.S. Preventive Services Task Force reaffirmation recommendation statement. Ann Intern Med. 2009; 150:869-873. [PubMed: 19528565]

39. Barclay S, Pol S, Mutimer D, Benhamou Y, Mills PR, Hayes PC, Cameron S, Carman W. Erratum to 'The management of chronic hepatitis B in the immunocompromised patient: recommendations from a single topic meeting' [J. Clin. Virol. 41(4), 2008, pp. 243-254]. J Clin Virol. 2008; 42:104115. [PubMed: 18572428]

40. Yagci M, Ozkurt ZN, Yegin ZA, Aki Z, Sucak GT, Haznedar R. Hepatitis B virus reactivation in HBV-DNA negative and positive patients with hematological malignancies. Hematol. 2010; 15:240-244.

41. Kim YM, Jeong SH, Kim JW, Lee SH, Hwang JH, Park YS, Kim N, Lee JS, Kim HY, Lee DH. Chronic hepatitis B, non-Hodgkin's lymphoma, and effect of prophylactic antiviral therapy. J Clin Virol. 2011; 51:241-245. [PubMed: 21628103]

42. Mya DH, Han ST, Linn YC, Hwang WY, Goh YT, Tan DC. Risk of hepatitis B reactivation and the role of novel agents and stem-cell transplantation in multiple myeloma patients with hepatitis B virus (HBV) infection. Ann Oncol. 2012; 23:421-426. [PubMed: 21551005]

43. Zelenetz AD, Abramson JS, Advani RH, Andreadis CB, Bartlett N, Bellam N, Byrd JC, Czuczman MS, Fayad LE, Glenn MJ, Gockerman JP, Gordon LI, Harris NL, Hoppe RT, Horwitz SM, Kelsey CR, Kim YH, LaCasce AS, Nademanee A, Porcu P, Press O, Pro B, Reddy N, Sokol L, Swinnen LJ, Tsien C, Vose JM, Wierda WG, Yahalom J, Zafar N. Non-Hodgkin's lymphomas. J Natl Compr Cancer Netw. 2011; 9:484-560.

44. Idilman R, Arat M. Evaluation and management of hepatitis B virus infection in hematopoietic stem cell transplantation: before and after transplantation. Expert Rev Anti Infect Ther. 2011; 9:641-652. [PubMed: 21819330]

45. Yeo W, Chan TC, Leung NWY, Lam WY, Mo FKF, Chu MT, Chan HLY, Hui EP, Lei KIK, Mok TSK, Chan PKS. Hepatitis B virus reactivation in lymphoma patients with prior resolved hepatitis B undergoing anticancer therapy with or without rituximab. J Clin Oncol. 2009; 27:605-611. [PubMed: 19075267]

46. Leung C, Tsoi E, Burns G, Sievert W. An argument for the universal prophylaxis of hepatitis B infection in patients receiving rituximab: a 7-year institutional experience of hepatitis screening. Oncologist. 2011; 16:579-584. [PubMed: 21464465] 
47. Tsutsumi Y, Yamamoto Y, Tanaka J, Asaka M, Imamura M, Masauzi N. Prevention of hepatitis B virus reactivation under rituximab therapy. Immunotherapy. 2009; 1:1053-1061. [PubMed: 20635919]

48. Mendez-Navarro J, Corey KE, Zheng H, Barlow LL, Jang JY, Lin W, Zhao H, Shao R-X, McAfee SL, Chung RT. Hepatitis B screening, prophylaxis and re-activation in the era of rituximab-based chemotherapy. Liver Int. 2011; 31:330-339. [PubMed: 20738779]

49. Evens AM, Jovanovic BD, Su YC, Raisch DW, Ganger D, Belknap SM, Dai MS, Chiu BC, Fintel B, Cheng Y, Chuang SS, Lee MY, Chen TY, Lin SF, Kuo CY. Rituximab-associated hepatitis B virus (HBV) reactivation in lymphoproliferative diseases: meta-analysis and examination of FDA safety reports. Ann Oncol. 2011; 22:1170-1180. [PubMed: 21115603]

50. Cil T, Altintas A, Tuzun Y, Pasa S, Isikdogan A. Hepatitis B virus reactivation induced by yttrium-90-ibritumomab-tiuxetan. Leuk Lymphoma. 2007; 48(9):1866-1868. [PubMed: 17786727]

51. Iannitto E, Minardi V, Calvaruso G, Mule A, Ammatuna E, Di Trapani R, Ferraro D, Abbadessa V, Craxi A, Di Stefano R. Hepatitis B virus reactivation and alemtuzumab therapy. Eur J Haematol. 2005; 74:254-258. [PubMed: 15693796]

52. Aomatsu T, Komatsu H, Yoden A, Hosomi A, Miyazaki H, Sogo T, Inui A, Fujisawa T, Tamai H. Fulminant hepatitis B and acute hepatitis B due to intrafamilial transmission of HBV after chemotherapy for non-Hodgkin's lymphoma in an HBV carrier. Eur J Pediatr. 2010; 169:167-171. [PubMed: 19466454]

53. Rago A, Ridola L, Lichtner M, Mecarocci S, Marocco R, Cenfra N, Belvisi V, Mastroianni CM, Cimino G. Hepatitis B reactivation despite entecavir prophylaxis in a patient with chronic lymphocytic leukaemia receiving bendamustine. J Antimicrob Chemother. 2012; 67:510-511. [PubMed: 22110085]

54. Tapan U, May SK, Fiore J, Kozyreva O. Reactivation of hepatitis B virus following bendamustinecontaining chemotherapy in a patient with multiple myeloma. Leuk Lymphoma. 2011; 52:916918. [PubMed: 21306291]

55. Cortelezzi A, Vigano M, Zilioli VR, Fantini NN, Pasquini MC, Deliliers GL, Colombo M, Lampertico P. Adefovir added to lamivudine for hepatitis B recurrent infection in refractory B-cell chronic lymphocytic leukemia on prolonged therapy with Campath-1 H. J Clin Virol. 2006; 35:467-469. [PubMed: 16316778]

56. Ikeda K, Shiga Y, Takahashi A, Kai T, Kimura H, Takeyama K, Noji H, Ogawa K, Nakamura A, Ohira H, Sato Y, Maruyama Y. Fatal hepatitis B virus reactivation in a chronic myeloid leukemia patient during imatinib mesylate treatment. Leuk Lymphoma. 2006; 47:155-157. [PubMed: 16321842]

57. Yun J, Kim KH, Kang ES, Gwak GY, Choi MS, Lee JE, Nam SJ, Yang JH, Park YH, Ahn JS, Im YH. Prophylactic use of lamivudine for hepatitis B exacerbation in post-operative breast cancer patients receiving anthracycline-based adjuvant chemotherapy. Br J Cancer. 2011; 104:559-563. [PubMed: 21285992]

58. Yeo W, Chan PKS, Hui P, Ho WM, Lam KC, Kwan WH, Zhong S, Johnson PJ. Hepatitis B virus reactivation in breast cancer patients receiving cytotoxic chemotherapy: a prospective study. $\mathrm{J}$ Med Virol. 2003; 70:553-561. [PubMed: 12794717]

59. Grewal J, Dellinger CA, Yung WK. Fatal reactivation of hepatitis B with temozolomide. N Engl J Med. 2007; 356:1591-1592. [PubMed: 17429098]

60. Eren OO, Artac M, Boruban MC, Yavas O, Arslan U, Basaranoglu M. Chemotherapy-induced Hepatitis B virus reactivation in HbsAg positive cancer patients: a single center experience. Med Oncol. 2009; 26:386-392. [PubMed: 19021003]

61. Yeo W, Johnson PJ. Diagnosis, prevention and management of hepatitis B virus reactivation during anticancer therapy. Hepatology. 2006; 43:209-220. [PubMed: 16440366]

62. Zhong S, Yeo W, Schroder C, Chan PK, Wong WL, Ho WM, Mo F, Zee B, Johnson PJ. High hepatitis B virus (HBV) DNA viral load is an important risk factor for HBV reactivation in breast cancer patients undergoing cytotoxic chemotherapy. J Viral Hepat. 2004; 11:55-59. [PubMed: 14738558] 
63. Lau GK. Hepatitis B reactivation after chemotherapy: two decades of clinical research. Hepatol Int. 2008; 2:152-162. [PubMed: 19669300]

64. Ayoub WS, Keeffe EB. Review article: current antiviral therapy of chronic hepatitis B. Aliment Pharmacol Ther. 2011; 34:1145-1158. [PubMed: 21978243]

65. Kwon H, Lok AS. Hepatitis B therapy. Nat Rev Gastroenterol Hepatol. 2011; 8:275-284. [PubMed: 21423260]

66. Shamliyan TA, Johnson JR, MacDonald R, Shaukat A, Yuan JM, Kane RL, Wilt TJ. Systematic review of the literature on comparative effectiveness of antiviral treatments for chronic hepatitis $\mathrm{B}$ infection. J Gen Intern Med. 2011; 26:326-339. [PubMed: 21203860]

67. Loomba R, Rowley A, Wesley R, Liang TJ, Hoofnagle JH, Pucino F, Csako G. Systematic review: the effect of preventive lamivudine on hepatitis B reactivation during chemotherapy. Ann Intern Med. 2008; 148:519-528. [PubMed: 18378948]

68. Ziakas PD, Karsaliakos P, Mylonakis E. Effect of prophylactic lamivudine for chemotherapyassociated hepatitis B reactivation in lymphoma: a meta-analysis of published clinical trials and a decision tree addressing prolonged prophylaxis and maintenance. Haematologica. 2009; 94:9981005. [PubMed: 19454492]

69. Katz LH, Fraser A, Gafter-Gvili A, Leibovici L, Tur-Kaspa R. Lamivudine prevents reactivation of hepatitis B and reduces mortality in immunosuppressed patients: systematic review and metaanalysis. J Viral Hepat. 2008; 15:89-102. [PubMed: 18184191]

70. Hann HW, Gregory VL, Dixon JS, Barker KF. A review of the one-year incidence of resistance to lamivudine in the treatment of chronic hepatitis B: lamivudine resistance. Hepatol Int. 2008; 2:440-456. [PubMed: 19669319]

71. Deutsch M, Papadopoulos N, Manolakopoulos S, Hatziyanni E, Vassilopoulos D. Fatal hepatitis B virus reactivation due to a lamivudine mutant despite undetectable initial viral load. Eur $\mathbf{J}$ Gastroenterol Hepatol. 2011; 23:109. [PubMed: 21139472]

72. Brost S, Schnitzler P, Stremmel W, Eisenbach C. Entecavir as treatment for reactivation of hepatitis B in immunosuppressed patients. World J Gastroenterol. 2010; 16:5447-5451. [PubMed: 21086562]

73. Uchiyama M, Tamai Y, Ikeda T. Entecavir as prophylaxis against hepatitis B virus reactivation following chemotherapy for lymphoma. Int J Infect Dis. 2010; 14:e265-e266. [PubMed: 19665406]

74. Li HR, Huang JJ, Guo HQ, Zhang X, Xie Y, Zhu HL, Zhai LZ, Pu XX, Huang Y, Guo CC, Lin TY. Comparison of entecavir and lamivudine in preventing hepatitis B reactivation in lymphoma patients during chemotherapy. J Viral Hepat. 2011; 18:877-883. [PubMed: 21054683]

75. Colson P, Borentain P, Coso D, Chabannon C, Tamalet C, Gerolami R. Entecavir as a first-line treatment for HBV reactivation following polychemotherapy for lymphoma. Br J Haematol. 2008; 143:148-150. [PubMed: 18710387]

76. Gish RG, Lok AS, Chang TT, de Man RA, Gadano A, Sollano J, Han KH, Chao YC, Lee SD, Harris M, Yang J, Colonno R, Brett-Smith H. Entecavir therapy for up to 96 weeks in patients with HBeAg-positive chronic hepatitis B. Gastroenterology. 2007; 133:1437-1444. [PubMed: 17983800]

77. Lai CL, Shouval D, Lok AS, Chang TT, Cheinquer H, Goodman Z, DeHertogh D, Wilber R, Zink RC, Cross A, Colonno R, Fernandes L. Entecavir versus lamivudine for patients with $\mathrm{HBeAg}$ negative chronic hepatitis B. N Engl J Med. 2006; 354:1011-1020. [PubMed: 16525138]

78. Watanabe M, Shibuya A, Takada J, Tanaka Y, Okuwaki Y, Minamino T, Hidaka H, Nakazawa T, Koizumi W. Entecavir is an optional agent to prevent hepatitis B virus (HBV) reactivation: a review of 16 patients. Eur. 2010; 21:333-337.

79. Wong VW, Wong GL, Yiu KK, Chim AM, Chu SH, Chan HY, Sung JJ, Chan HL. Entecavir treatment in patients with severe acute exacerbation of chronic hepatitis B. J Hepatol. 2011; 54:236-242. [PubMed: 21030105]

80. Saab S, Dong MH, Joseph TA, Tong MJ. Hepatitis B prophylaxis in patients undergoing chemotherapy for lymphoma: a decision analysis model. Hepatology. 2007; 46:1049-1056. [PubMed: 17680650] 
81. Day FL, Karnon J, Rischin D. Cost-effectiveness of universal hepatitis B virus screening in patients beginning chemotherapy for solid tumors. J Clin Oncol. 2011; 29:3270-3277. [PubMed: 21788556]

82. Zurawska U, Hicks LK, Woo G, Bell CM, Krahn M, Chan KK, Feld JJ. Hepatitis B virus screening before chemotherapy for lymphoma: a cost-effectiveness analysis. J Clin Oncol. 2012

83. Raimondo G, Pollicino T, Cacciola I, Squadrito G. Occult hepatitis B virus infection. J Hepatol. 2007; 46:160-170. [PubMed: 17112622]

84. Ocana S, Casas ML, Buhigas I, Lledo JL. Diagnostic strategy for occult hepatitis B virus infection. World J Gastroenterol. 2011; 17:1553-1557. [PubMed: 21472120]

85. Urbani S, Fagnoni F, Missale G, Franchini M. The role of anti-core antibody response in the detection of occult hepatitis B virus infection. Clin Chem Lab Med. 2010; 48:23-29. [PubMed: 19919328]

86. Shih LN, Sheu JC, Wang JT, Huang GT, Yang PM, Lee HS, Sung JL, Wang TH, Chen DS. Serum hepatitis B virus DNA in healthy HBsAg-negative Chinese adults evaluated by polymerase chain reaction. J Med Virol. 1990; 32:257-260. [PubMed: 2081972]

87. Wang JT, Wang TH, Sheu JC, Shih LN, Lin JT, Chen DS. Detection of hepatitis B virus DNA by polymerase chain reaction in plasma of volunteer blood donors negative for hepatitis B surface antigen. J Infect Dis. 1991; 163:397-399. [PubMed: 1988524]

88. Luo KX, Zhou R, He C, Liang ZS, Jiang SB. Hepatitis B virus DNA in sera of virus carriers positive exclusively for antibodies to the hepatitis B core antigen. J Med Virol. 1991; 35:55-59. [PubMed: 1940884]

89. Arnold DM, Crowther MA, Meyer RM, Carruthers J, Ditomasso J, Heddle NM, McLeod A, Kelton JG. Misleading hepatitis B test results due to intravenous immunoglobulin administration: implications for a clinical trial of rituximab in immune thrombocytopenia. Transfusion. 2010; 50:2577-2581. [PubMed: 20576011]

90. Pei SN, Ma MC, Wang MC, Kuo CY, Rau KM, Su CY, Chen CH. Analysis of hepatitis B surface antibody titers in B cell lymphoma patients after rituximab therapy. Ann Hematol. 2012; 91:10071012. [PubMed: 22273839]

91. Fukushima N, Mizuta T, Tanaka M, Yokoo M, Ide M, Hisatomi T, Kuwahara N, Tomimasu R, Tsuneyoshi N, Funai N, Sueoka E. Retrospective and prospective studies of hepatitis B virus reactivation in malignant lymphoma with occult HBV carrier. Ann Oncol. 2009; 20:2013-2017. [PubMed: 19561036]

92. Koo YX, Tay M, Teh YE, Teng D, Tan DS, Tan IB, Tai DW, Quek R, Tao M, Lim ST. Risk of hepatitis B virus (HBV) reactivation in hepatitis B surface antigen negative/hepatitis B core antibody positive patients receiving rituximab-containing combination chemotherapy without routine antiviral prophylaxis. Ann Hematol. 2011; 90:1219-1223. [PubMed: 21520001]

93. Wu J-M, Huang Y-H, Lee P-C, Lin H-C, Lee S-D. Fatal reactivation of hepatitis B virus in a patient who was hepatitis B surface antigen negative and core antibody positive before receiving chemotherapy for non-Hodgkin lymphoma. J Clin Gastroenterol. 2009; 43:496-498. [PubMed: 19247200]

94. Law JK, Ho JK, Hoskins PJ, Erb SR, Steinbrecher UP, Yoshida EM. Fatal reactivation of hepatitis B post-chemotherapy for lymphoma in a hepatitis B surface antigen-negative, hepatitis B core antibody-positive patient: potential implications for future prophylaxis recommendations. Leuk Lymphoma. 2005; 46:1085-1089. [PubMed: 16019563]

95. Ferraro D, Pizzillo P, Di Marco V, Vultaggio A, Iannitto E, Venezia G, Craxi A, Di Stefano R. Evaluating the risk of hepatitis $\mathrm{B}$ reactivation in patients with haematological malignancies: is the serum hepatitis B virus profile reliable? Liver Int. 2009; 29:1171-1177. [PubMed: 19602139]

96. Rossi D, Sala L, Minisini R, Fabris C, Falleti E, Cerri M, Burlone ME, Toniutto P, Gaidano G, Pirisi M. Occult hepatitis B virus infection of peripheral blood mononuclear cells among treatment-naive patients with chronic lymphocytic leukemia. Leuk Lymphoma. 2009; 50:604-611. [PubMed: 19373659]

97. Ji D, Cao J, Hong X, Li J, Wang J, Chen F, Wang C, Zou S. Low incidence of hepatitis B virus reactivation during chemotherapy among diffuse large B-cell lymphoma patients who are HBsAg- 
negative/ HBcAb-positive: a multicenter retrospective study. Eur J Haematol. 2010; 85:243-250. [PubMed: 20491883]

98. Cheung W-I, Chan HL-Y, Leung VK-S, Tse C-H, Fung K, Lin S-Y, Wong A, Wong VW-S, Chau T-N. Reactivation of hepatitis B virus infection with persistently negative HBsAg on three HBsAg assays in a lymphoma patient undergoing chemotherapy. J Clin Virol. 2010; 47:193-195. [PubMed: 20031483]

99. Zhang B, Wang J, Xu W, Wang L, Ni W. Fatal reactivation of occult hepatitis B virus infection after rituximab and chemotherapy in lymphoma: necessity of antiviral prophylaxis. Onkologie. 2010; 33:537-539. [PubMed: 20926902]

100. Koo YX, Tan DS, Tan IB, Quek R, Tao M, Lim ST. "Anti-HBc alone” in human immunodeficiency virus-positive and immuno-suppressed lymphoma patients. World J Gastroenterol. 2009; 15:3834-3835. [PubMed: 19673031]

101. Hui C-K, Cheung WWW, Zhang H-Y, Au W-Y, Yueng Y-H, Leung AYH, Leung N, Luk JM, Lie AKW, Kwong Y-L, Liang R, Lau GKK. Kinetics and risk of de novo hepatitis B infection in HBsAg-negative patients undergoing cytotoxic chemotherapy. Gastroenterology. 2006; 131:5968. [Erratum appears in Gastroenterology. 2006 Oct;131(4):1363]. [PubMed: 16831590]

102. Liu CY, Chandrasekar PH, Masood A, Schiffer CA. Adherence to hepatitis B screening and prophylactic lamivudine for prevention of rituximab-associated hepatitis B reactivation. J Oncol Pharm Prac. 2012

103. Larrubia JR. Occult hepatitis B virus infection: a complex entity with relevant clinical implications. World J Gastroenterol. 2011; 17:1529-1530. [PubMed: 21472115]

104. Lim SM, Jang JW, Kim BW, Choi H, Choi KY, Park SJ, Han CW. Hepatitis B virus reactivation during chlorambucil and prednisolone treatment in an HBsAg-negative and anti-HBs-positive patient with B-cell chronic lymphocytic leukemia. Korean J Hepatol. 2008; 14:213-218. [PubMed: 18617769]

105. Senecal D, Pichon E, Dubois F, Delain M, Linassier C, Colombat P. Acute hepatitis B after autologous stem cell transplantation in a man previously infected by hepatitis B virus. Bone Marrow Transplant. 1999; 24:1243-1244. [PubMed: 10642815]

106. Awerkiew S, Daumer M, Reiser M, Wend UC, Pfister H, Kaiser R, Willems WR, Gerlich WH. Reactivation of an occult hepatitis B virus escape mutant in an anti-HBs positive, anti-HBc negative lymphoma patient. J Clin Virol. 2007; 38:83-86. [PubMed: 17134939]

107. Palmore TN, Shah NL, Loomba R, Borg BB, Lopatin U, Feld JJ, Khokhar F, Lutchman G, Kleiner DE, Young NS, Childs R, Barrett AJ, Liang TJ, Hoofnagle JH, Heller T. Reactivation of hepatitis B with reappearance of hepatitis B surface antigen after chemotherapy and immunosuppression. Clin Gastroenterol Hepatol. 2009; 7:1130-1137. [PubMed: 19577007]

108. Niitsu N, Hagiwara Y, Tanae K, Kohri M, Takahashi N. Prospective analysis of hepatitis B virus reactivation in patients with diffuse large B-cell lymphoma after rituximab combination chemotherapy. J Clin Oncol. 2010; 28:5097-5100. [PubMed: 20837949]

109. Strobel E, Schoniger M. False-positive hepatitis serology after administration of immunoglobulins. Dtsch Med Wochenschr. 2006; 131:1325-1327. [PubMed: 16761202] 


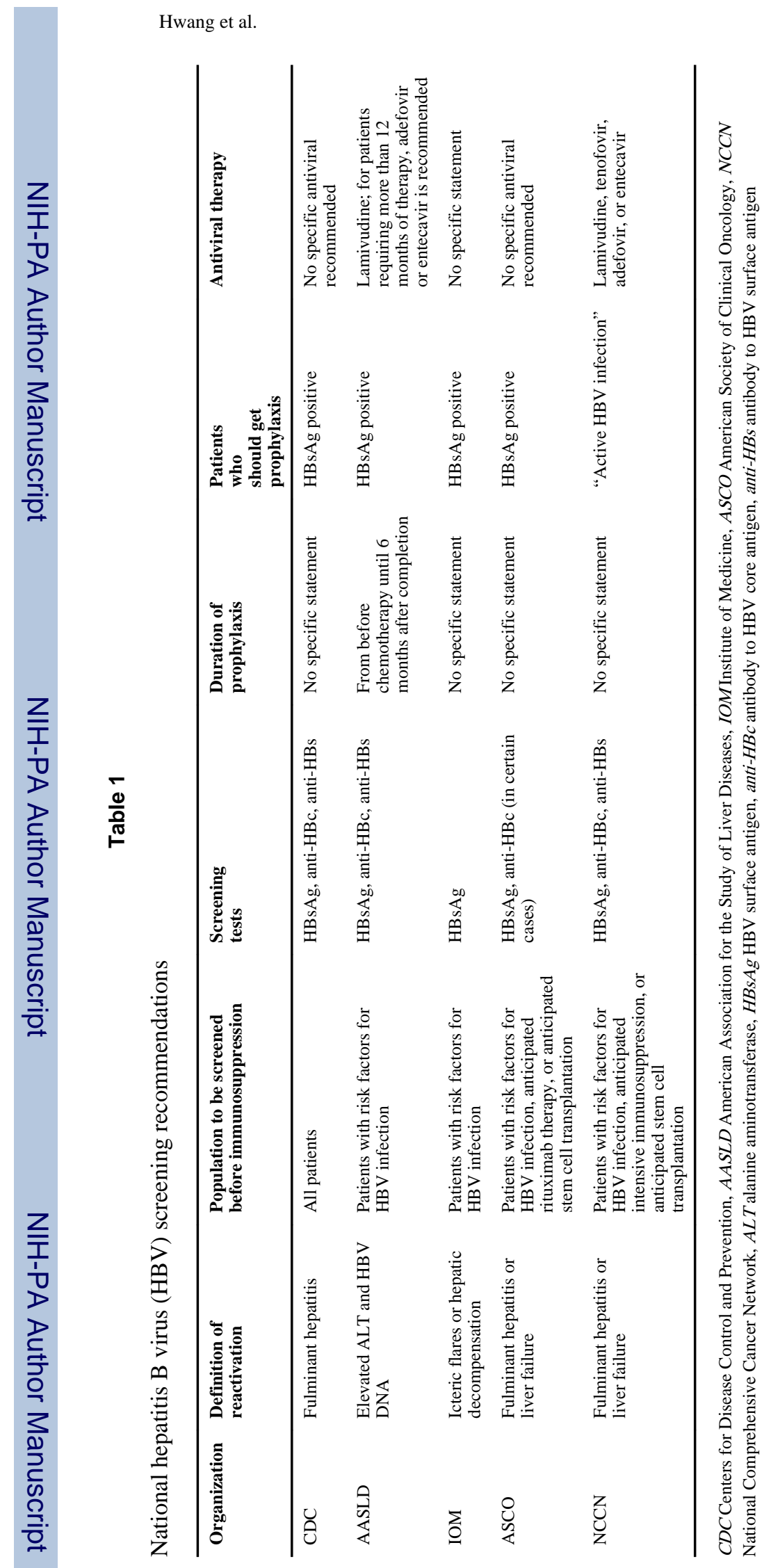

Page 16 
Table 2

Serologic screening tests and clinical scenarios

\begin{tabular}{lllll}
\hline Interpretation & $\begin{array}{l}\text { HBV } \\
\text { surface } \\
\text { antigen } \\
\text { (HBsAg) }\end{array}$ & $\begin{array}{l}\text { Antibody } \\
\text { to HBV } \\
\text { core } \\
\text { antigen } \\
\text { (anti-HBc) }\end{array}$ & $\begin{array}{l}\text { Antibody to } \\
\text { HBV } \\
\text { surface } \\
\text { antigen } \\
\text { (anti-HBs) }\end{array}$ & $\begin{array}{l}\text { HBV } \\
\text { DNA }\end{array}$ \\
\hline Chronic infection & + & + & - & + \\
Carrier state & + & + & - & - \\
Convalescent from previous infection & - & + & + & - \\
Occult infection & - & + & - & $+{ }^{a}$ \\
Prior vaccination & - & - & + & - \\
\hline
\end{tabular}

${ }^{a}$ If sensitive quantitative assays with limits of detection $5 \mathrm{IU} / \mathrm{mL}$ are used 